\author{
Anna Horodecka \\ Warsaw School of Economics \\ e-mail: ahorod@sgh.waw.pl \\ Liudmyla Vozna \\ Independent Researcher \\ e-mail: ludmila.vozna@gmail.com
}

\title{
A NEW PARADIGM OF ECONOMIC POLICY BASED ON THE SYNTHESIS OF ORTHODOX AND HETERODOX ECONOMICS
}

\section{NOWY PARADYGMAT POLITYKI GOSPODARCZEJ OPARTY NA SYNTEZIE ORTODOKSYJNEJ I HETERODOKSYJNEJ EKONOMII}

DOI: $10.15611 /$ pn.2017.489.12

JEL Classification: B4, B52, E61, H110, I3

Summary: The article challenges the economic policy based only on mainstream economics and asserts the necessity of the elaboration of new approach to economic policy based on the synthesis of orthodox and heterodox economics. It presents some key ideas of heterodox economics, which can fill gaps of mainstream economics. The article regards issues such as sustainable growth, the problem of poverty, rationality and motivation of economic actors from the point of view of ecological, humanistic, feminist, institutional and behavioral economics respectively. The new approach should be based on the complexity and evolutionary approach, according to which the economic system is a part of the bigger meta-system, and, thus, the goals of economic policy should respect the meta-goal of the state policy related to the survival of the society and its natural, social and ethical environment.

Keywords: economic policy, heterodox economics, goals of economic policy, complexity, paradigm.

Streszczenie: W artykule kwestionuje się politykę gospodarczą opierającą się jedynie na ekonomii głównego nurtu i podkreśla konieczność opracowania nowego podejścia do polityki gospodarczej opartego na syntezie ortodoksyjnej i heterodoksyjnej ekonomii. Przedstawia się kilka kluczowych idei ekonomii heterodoksyjnej, która może wypełnić luki głównego nurtu ekonomii. Artykuł odnosi się do takich zagadnień jak zrównoważony wzrost, problem ubóstwa, racjonalności i motywacji podmiotów gospodarczych i rozważa je z punktu widzenia ekonomii ekologicznej, humanistycznej, feministycznej, instytucjonalnej i behawioralnej. Nowe podejście powinno opierać się na podejściu ekonomii złożoności i podejściu ewolucyjnej, zgodnie z którymi system gospodarczy jest częścią większego meta-systemu, a za- 
tem cele polityki gospodarczej powinny respektować meta-cel polityki państwa nastawionej na przetrwanie społeczeństwa i biorącej pod uwagę jego środowisko naturalne, społeczne i etyczne.

Słowa kluczowe: polityka gospodarcza, ekonomia heterodoksyjna, cele polityki gospodarczej, ekonomia złożoności, paradygmat.

\section{Introduction}

The political, social and economic trends (changes) that have occurred in many developed countries over the last three decades can be regarded as the important challenge for contemporary economic policy. Increasing globalization, growing environmental problems, deepening inequality between social groups and between countries, refugees' crisis in Europe, lack of control in the excessively increased financial sector and, especially, the Great Recession of 2007-2009 - all these challenges evidence some faults and even failures of economic policy traditionally implemented in many OECD countries.

Such a traditional policy is predominantly based on so called mainstream economics (or orthodox economics), which is most associated with neoclassical economics and neoclassical synthesis, whereas the latter combines neoclassical methods and the Keynesian approach to macroeconomics. Despite the significant differences between neoclassical and Keynesian approaches to macroeconomic policy, we can regard both as belonging to the same paradigm of the state regulation. Firstly, they have a common view on economic growth as one of the crucial goals of economic policy and on the methods of its calculation. Secondly, it is a similar view at economic system as relatively homogeneous (and accordingly, comparatively simple and linear) one, and, accordingly, the use of aggregate homogeneous functions (as, for example, the aggregate supply and aggregate demand). This feature is associated with a mechanistic understanding of the system's equilibrium (for example, it can be defined as a point of intersection of the curves of supply and demand). Thirdly, it is a similar view at economic system as comparatively autonomous and isolated from the socio-cultural, natural and political environment, i.e. the economic system is not regarded as the part of more complex meta-system [Horodecka 2008; Horodecka 2015a].

The alternative way of perceiving economic reality is presented by different schools of modern economic thought, which are known under such a general (rather conditional) name as heterodox economics, which encompasses: institutionalism, behavioral, evolutionary, ecological, feminist economics, socio-economics, humanistic economics (together with religiously motivated Buddhist, Islamic and Christian economics, mostly represented by Social Catholic Teaching) and some other schools. Despite serious differences between these schools, we can notice their certain similarities in relation to the economic policy conception. Thus, different schools of heterodox economics extend the range of economics to social, ecological, cultural 
and ethical issues and, accordingly, understand the goals of economic policy wider than mainstream economics does. Also, regarding these goals in the more complex context, the heterodox economics theorists pay special attention to the goals, which have a long-term orientation.

Considering some limitations of mainstream economics and failures of traditional economic policy (regarding goals and instruments) the question arises about the necessity to elaborate a new paradigm of economic policy based on the synthesis of orthodox and heterodox schools of economic thought. This necessity and some key features of such a paradigm are reflected, to some extent, in the Lisbon Strategy, in the Europe 2020 Strategy, and in OECD recommendations for economic policy. Thus, the EU strategy for sustainable development, adopted in 2001 in Gothenburg by the European Council, is calling for a more integrated approach to policy-making, i.e. economic, social and environmental goals should be achieved simultaneously. The Lisbon Strategy poses the task to transform the European Union economy into the most competitive and dynamic knowledge-based economy in the world, capable of sustainable economic growth with more and better jobs and greater social cohesion. The Europe 2020 Strategy considers the most important five objectives such as employment, research and innovation, climate change and energy, education, and the fight against poverty. The overall aim of the strategy is the sustainable growth, which can be understood as a "smart, sustainable and inclusive growth".

The aim of this paper is to present some key schools of heterodox economics and their ideas, which can fill the gaps of mainstream economics and can be also used as important components of a new paradigm of economic policy when it defines its goals and instruments. Combining the best orthodox and heterodox economics, the emerging paradigm of economic policy should be capable to meet challenges arising from the changes that occur in global economy and in economies of OECD countries.

\section{Sustainability instead the unlimited growth: the challenge from ecological economics}

According to the Europe 2020 Strategy, the economic growth should be sustainable. The concept of sustainable development, elaborated by ecological economics, focuses not on material advantages of people living in developed countries, but on fundamental human needs of the current and future generations in the whole world. Unlike the prevailing orthodox understanding of economic development, ecological economics points out to the necessity of the dematerialization of economic growth, and growing demand for eco-efficient services, rather than to increasing production and consumerism [Constanza 1989; Daly, Farley 2010].

Some decisions, which from the standpoint of standard economics seem to be efficient and therefore rational, in the light of ecological economics are irrational because of their risk for the environment and justice. Ecological economics opposes, therefore, the usage of only simple cost-benefit analysis and assumption about the 
full substitution of some products by others. The latter assumption actually means that unpolluted environment and clean water could be replaced by another product or service, which does not seem to be realistic.

The sustainability, according to modern heterodox ecological economics (in contrast to the neoclassical oriented environmental economics), means not only the achievement of selected ecological goals, but the fundamental change in the way of perceiving the reality, namely as interaction and interdependence of economic, biophysical, social and ethical world [Gowdy, Erickson 2005]. The social, political, economic and cultural systems are perceived as interconnected. According to ecological economics, the integration of such an interconnected view may affect the way of thinking, discussing and evaluating political economic decisions.

Some ecological economists [Femia et al. 2001] stress the fact that in the face of growing environmental problems, standard environment policy seems to be insufficient for providing a path for sustainable growth on a global scale. They point to the necessity of the complex strategy for reaching the environmental sustainability and individual prosperity. Economic policy goals should be considered regarding their impact on the environment and welfare. Moreover, the government should act on the meso-level as well strengthening the companies and individuals responsibility toward those goals [Tomer, Eikelenboom 2008].

Ecological economics, therefore, proposes a much more radical approach to the understanding of economic sustainability than the standard economics does, based on another vision of a human being [Jager, Janssen 2000] and his/her relation to the environment which translates into the new vision of the whole economy [Horodecka 2011].

\section{The fight with poverty: the approach of social, humanistic and feminist economics}

According to heterodox economic thought and some other current works (like this of Joseph Stiglitz [Stiglitz 2013]), the effect of poverty and inequality on the whole economy, whether measured by GDP growth and stability, or by wellbeing, is negative. Thus, sustainable development cannot be thought without social components [Azar et al. 1996]. Similarly, according to the Europe 2020 Strategy, the sustainable growth contains not only ecological goals, but as well social justice, equal opportunities, prevention of social exclusion and elimination of poverty.

Social components of economic development, especially the necessity to combat the poverty by means of economic reforms, were emphasized by old heterodox tradition (just to name Simonde de Sismondi, Karl Marx, Robert Owen, Henri Saint-Simon), and by some representatives of world religions. The modern heterodox economic thought, especially the socio-economic, feminist and, partly, humanistic one, having been based on their predecessors, provides the most important services to the understanding of the social oriented goals of the economic policy strategy [Lutz, Lux 1979; Horodecka 2016a; Horodecka 2015c]. 
The problem of poverty and social exclusion is one of key issues of religiously motivated Buddhist, Islamic and Christian economics. Thus, the idea of responsibility of the rich to the poor can be seen from the very beginning of Christianity. Alms had been considered as the worthy act of a good Christian at the very beginning of the Christianity. Later, the help to the poor got institutionalized by the ecclesiastical organizations (like monasteries) and some charity organizations co-working with the church. Finally, they took the form of the encyclical „Rerum Novarum” in 1891, in which welfare and solidarity with the poor took the form of recommendations for economic policy. The Christian religion owes its concern for the poor not only to the teaching of Christ, but as well to its Jewish roots. The Jewish tradition encompasses, especially in the Torah, the regulations concerning the care of widows, children and the poor, as well as ideas of social justice (especially well seen by prophets, like Isaiah for instance: Isaiah (Isa 1:10-17; 10,1-2).

The Jewish tradition together with the Christian provided foundations for the Islam and its ideas of social assistance. The tax for the poor, called zakat (the ultimate meaning of "purification of wealth" [Kuran 1997]), builds one of the main pillars of Islam. Helping other people by paying zakat, Muslim fulfils Qur'an. Zakat belongs to the important issues discussed in Islam economics as well, and can be understood as a part of financial worship [Benthall, Bellion-Jourdan 2009].

Thus, the Christian social doctrine helps to deepen the understanding of the principles of solidarity and subsidiarity, forming the economic foundations for social market economy as a characteristic of the European Union countries. The mentioned religious traditions demonstrate that social help, to be efficient, may be integrated in social structures and not just be left to the government. There are some small institutions which may be as well effective to combat the problem and, at the same time, growing the sense of responsibility for others by givers, and the sense of gratitude by the receivers - stringing the community sense, so the "inclusivity of the goal is more plausible. The person is not just left to the anonymity of the governing structures. Growth is not the real answer to the poverty, not only because the real problem seems to be in allocation, but as well because of loses within "relational goods"' [Mlcoch 2007].

Buddhist economics [Schumacher 1973; Payutto 1994] also devotes a lot of space to the poverty eradication offering quite interesting understanding of this phenomena. In general, it suggests the analysis of the poverty and inequality presenting it as the effect of greed, orientation on wants and not needs, which is supported by government policies [Daniels 2003]. In Buddhism, the poverty is regarded as one of the manifestations of dukha (ill-being, suffering). It is understood as a lack of material equipment for a decent life free from hunger, disease and danger. The main needs are food, clothing, housing and healthcare.

According to Buddhist economics, one of possible causes of poverty is the lack of knowledge about its sources. The principal source is the greed that manifests itself in wanting to consume more goods and services regardless one's proper needs. This leads to the pressure on efficiency and investing in technology, which should provide 
more and more of goods by lower costs. According to Buddhist economics, increasing the efficiency by increasing the demands does not solve the problem of poverty. Thus, the lack of attachment to goods, which could be popularized by means of education, informing about alternative life-styles, could prevent the phenomenon of poverty on such a large scale [Horodecka 2016b].

Furthermore, Buddhist economics indicates the impossibility of reconciling the goal of poverty elimination, with the aim of achieving economic growth at any price. Such a policy by rising the average income, increases inevitably the inequalities and thus deepens the feeling of poverty, on the one hand, and causes the inefficiency of the system, disrupting the basis of self-sufficiency economies of less developed countries. This makes the poor countries dependent on the richer ones, and reduces their ability to self-sufficiency and motivation to solve the problem of poverty using their own resources. Therefore, Buddhist economics is skeptical about the definition of poverty proposed by the World Bank, which uses average income as the reference to poverty, not mentioning the degree of satisfaction of those needs; and considers the development aid, implemented by the IMF and the World Bank, as supporting rather the interests of richer economies.

The problem of exclusion and the need to reduce it, is also discussed within social economics, and feminist economics [Horodecka 2015a]. One of prominent representatives of feminist economics, Nobel Prize winner, Amartya Sen emphasizes that the goal of economic policy can neither be only an increase in income nor traditional policy of redistribution. He focuses on provision of basic needs [Sen 2008]. These needs, when they are not covered, reduce the freedom of choice of the individual, which is necessary for effective decision-making. They encompass objective needs like food, health, home, heat, work, mode of transportation, allowing to gain a livelihood, which in turn help people to meet social needs. However, they depend on many factors influencing the amount of resources required for meeting these needs (capabilities) as a precondition to function in a society. Meeting the basic health, mobility or work needs for a disabled or ill person is more expensive than for a healthy one. Likewise, a person living in regions with very high or very low temperatures, has a higher expenditure on the provision of the temperature allowing for living. Similarly, someone, living in a region with strong prejudices minorities, stereotypes and constraints, must bear extra costs of meeting the same needs.

\section{What policy-makers should know about rationality and motivation: the warning from behavioral and institutional economics}

Inefficiency (or even failures) of some actions of economic policy can be the result of the simplified understanding of rationality. The assumption about human rationality is the methodological basis of many models elaborated by mainstream economics. The latter, predominantly neoclassical economics, relates the rationality of economic 
actors with their utility maximizing behavior. Thus, on the one hand, whereas the concept of rationality depends on the understanding of reasons of human action and choice, neoclassical economics treats the human nature and human motivation as comparatively simple. On the other hand, the neoclassical assumption about economic rationality (implicitly) means the knowledge of the perfect information. The both assumptions, according with heterodox economics, are unrealistic.

For now, we can observe a major shift in the concept of rationality as response to the economic crisis coming both from orthodox and heterodox economics. However, the changes proposed by heterodox economics are much deeper and base principally on the shift from individual rationality towards macroeconomic rationality. Whereas the major part of orthodox economics starts at individual rationality and looks for chances, opportunities and possible problems on the way between individual rationality and macro-rationality, the modern heterodox economics starts its understanding by the macro-rationality defining the goals which should be reached normatively, explaining them by the necessity of survival of the human race (ecological economic, evolutionary economics), social justice (feminist economics), or individual development in coherence with the social development (humanist economics) [Horodecka 2017].

In general, the majority of heterodox economic thoughts stresses the complexity of economic phenomena, including rationality. Complex rationality corresponds to complex motivation. As an illustration of these differences, we can regard the process of technical progress, innovations and knowledge. For example, mainstream economics perceives investments in human capital as the best method to support economic growth, as soon as they increase the innovation rate. R\&D and education expenses as percent to GDP would be favored. The heterodox economics, starting with viewing economic processes in a complex way, views the aspect of knowledge and innovation differently - perceiving its social (e.g. individualistic, collective society), cultural (for instance: gender - biased in feminist economist [Peter 2003]), and ecological embedding.

The institutional thought examines the process of technical progress not only from the individualistic perspective, but analyses social and cultural institutions, which can harm or foster the development of innovation and knowledge. It tries to answer the questions such as, whether a society is open-minded, there is the interest from companies in new inventions, what may harm them, what is the cooperation between universities and companies, etc.

When we are dealing with obtaining qualification, we can look more intensively at the motivation strategies. Is it, for example, enough to motivate students by ECTS points and by paying the researcher for IF-points gained, or should we lean on the more complex methods of evaluation, which foster team-work, exchange, intrinsic motivation and the development of individual's potential?

It is behavioral economics that, leaning on social psychology, gives a great insight in social processes and motives leading to specific behavior. It is for instance the tendency to the middle - the approval of dominant statements, i.e. the conformism, 
which can block the novelty. Social psychology proposes some mechanisms, which can block these negative tendencies, which largely depend on culture. It advises to implement (in companies) the methods of "the failure culture" or "to slow down time" (giving more time to take the choice), whereas these negative tendencies may be the effect of fast thinking [Tversky, Kahneman 1974].

\section{What is the meta-goal of economic policy? The possible answer from the position of evolutionary approach}

The mentioned failures of economic policy based on the mainstream paradigm consist in considering the economic system as comparatively autonomous, historyindependent and isolated from the socio-cultural, natural and political environment, i.e. the economic system is not regarded as a part of more complex and changing meta-system. Due to its mainly positive approach and model orientation, orthodox economics does not meet the challenges created by evolving complex socialeconomic-environmental structures, which constitutes the modern economic reality. That is why it seems that mainstream economics, using the words of Elsner, offers "noncomplex advice for complex problems" [Elsner et al. 2014].

As an illustration of a simplified approach in economic policy we can regard the (neoliberal) idea about efficiency of market regulators, inefficiency of public sector and, thus, the recommendation of the total privatization of state enterprises. Such a "simple" solution, under conditions of the absence of appropriate (social, political, economic and legal) institutions, for example, in Russia and Ukraine, during the 1990 s, led to the sharp growth of inequality, formation of oligarchy structures in economy and policy, increasing corruption, including political one, and formation of institutional traps of technological backwardness and poverty. Paradoxically, but the thesis about the necessity of the total private property and market economy (pure capitalism) becomes to be like the communistic idea about total state property and control (pure socialism) as much as both ideas are based on the extremely simplified understanding of very complex social-economic reality.

The fundamentally different position is presented by schools of heterodox economics such as institutional, evolutionary, ecological and complex economics which regard the economy as a complex, adaptive, dynamic, open, non-equilibrium, non-ergodic and path-dependent system [Elsner et al. 2014; Adkisson 2009; Foster 2006; Hodgson 2004].

Unlike neoclassical economics that defines different optimum points (as the point of market equilibrium, a consumer optimum, a producer optimum, etc.), evolutionary economics, together with institutional economics, also considers heterogeneity, variety and structures [Nelson, Winter 1982; Hodgson 2004]. Evolution, in its turn, can be perceived as the continuous or erratic/volatile deformation of model structures. Similarly, with synergetics, the evolutionary economic methodology operates with 
such terms as evolution, self-organized change, self-transformation and dissipative structures [Nelson, Winter 1982].

Complexity and evolutionary approach calls into question some of the fundamental concepts of mainstream economics such as, for example, the thesis about efficiency of the market with perfect competition, or considering the market (economic) equilibrium as an equilibrium between demand and supply, i.e. from mechanical point of view [Vozna 2016; Vozna 2013; Horodecka 2017; Horodecka 2015b]. Whereas complexity is, primarily, the property of living systems, the growth of the complexity of economic systems encourages us to analyze the latter also as living ones. It means that considering the economic systems as living ones we should not associate their equilibrium state with mechanical or thermodynamic equilibrium but rather with homeostasis and (or) their viability.

Precisely the viability (survival) of the (corresponding) human community can be considered as a principal goal of a state activity in general, and of economic policy as well. Such a supposition, on the one hand, is in accordance with political and philosophical views of John Locke, who (in 1689) pointed to the preservation of society and its every member as to the first and basic natural law that should be subject to the legislative power [Locke, Laslett 1988].

On the other hand, supposing the viability (survival) of the human community (society) as the meta-goal of the state policy, we underline the system-formation function of the state and, simultaneously, can analogize this type of a state with a long-lived company in the conception of Arie de Geus. The latter [De Geus 2007] characterizes such companies as living ones, which, unlike economic companies that define their life in economic terms, understand their life in the terms of own evolution. Among the main characteristics of living companies are the following ones: their employees all felt like parts of a whole; they must be willing to change in order to succeed; they value people, not assets; to them, assets and profits are like oxygen: necessary for life but not the purpose of life; people are hired into a living company with the understanding that they are there to develop their potential; in general, the living companies are the self-perpetuating work communities [De Geus 2007].

From the presented point of view, in accordance to which the meta-goal of the state-policy is the viability (survival) of a human community (society, human race, etc.), the principal criterion of the efficiency of the state policy should be the lifetime, i.e. the longevity of the community (society) under consideration. While speaking about the survival of a society, we should regard the latter as a complex system with a variety of characteristics such as demographic, cultural, educational, territorial, cultural historical heritage, natural environment, etc.

\section{Conclusions}

In the face of growing complexity of economic reality and in view of limitations of mainstream economics and some failures of traditional economic policy (from 
the standpoint of the both goals and instruments), the question arises about the necessity to elaborate a new paradigm of economic policy based on the synthesis of orthodox and heterodox schools of economic thought. The paper provides the analysis of some key schools of heterodox economics and their ideas, which can fill the gaps of mainstream economics and can be used as important components of a new paradigm of economic policy when it defines its goals and instruments. Heterodox economics, extending the range of economics to social, ecological and ethical issues, understands the economic policy goals more widely and deeply than the traditional objectives of economic. On the one hand, it gives them deeper and more complex meaning considering as well contextual factors. On the other hand, according to different schools of heterodox economics, economic policy goals have to be oriented on long-term perspectives and visions.

The failures of economic policy based on the mainstream orthodox paradigm are associated with simplified understanding of rationality of economic actors and considering the economic system as comparatively autonomous, history-independent and isolated from the socio-cultural, natural and political environment, i.e. the economic system is not regarded as the part of more complex and changing meta-system. To understand better the problem of economic policy in its relation to complexity, we can consider the human organism with cancer-illness. The cancer cells in the organism may have their goal to grow and expand. This goal is not compatible with the goal of the whole organism, which would die within a few years, if the system does not block their growth. What is rational for cancer-cells is not rational for the superior-system - the body. Thus, the answer, what is desirable, varies depending on the perspective of different systems under consideration, and it is not clear what system is superior to the other. Is it, for instance, the ecological system or the knowledge system? The knowledge can help to reduce the negative ecological impact of the human even more than the "simple" death. But the same knowledge is used as radiology not only for curing a person, but also for making atom bombs, as it happened with the discovery of Maria Curie-Skłodowska.

Thus, maybe the final answer, what system is "right", depends on ethical discourse, which starts with the question, what is "good" and what is "bad", which reflects the cultural development of the society. This ethical discourse is more complex than only the question what is more efficient or utile, and can occur on communicative basis (like, for instance, [Habermas 1987] suggests in his discourse on ethics). Social system, due to its complexity, cannot be grasped by laws of nature, which can suit for simple systems or an individual mind. As much as the economic system (and market, especially together with government) is the evolving part of social system [Colander, Kupers 2014; Felber 2010], the rules cannot be delivered from partial system, but from meta-system: they start with norms and values common for a society, i.e. in ethical discourse and ethical principles of social and ecological system, which varies in times and places.

In summary, basing on heterodox economics teaching, primarily - on evolutionary economics approach, we propose to consider the viability (survival) of the society 
(community, the unity of communities) as a meta-goal of economic policy. It means that the economic policy of EU must also obey this meta-goal. The latter, in its turn, implies not only the physical (demographical) preservation of the society, but also the survival of those European values and principles which were declared by the great philosophers of the Age of Enlightenment and which constitute the ethical and ideological basis of the modern civil society of the EU countries.

\section{References}

Adkisson R.V., 2009, The Economy as an Open System, [in:] T. Natarajan, W. Elsner, S. Fullwiler (eds.), Institutional Analysis and Practice, pp. 25-38, Springer, New York.

Azar C., Holmberg J., Lindgren K., 1996, Socio-ecological indicators for sustainability, Ecological Economics, vol. 18, no. 2, pp. 89-112.

Benthall J., Bellion-Jourdan J., 2009, The Charitable Crescent. Politics of Aid in the Muslim World, I.B.Tauris, London.

Colander D., Kupers R., 2014, Complexity and the Art of Public Policy: Solving Society's Problems from the Bottom up, Princeton University Press, Princeton.

Constanza R., 1989, What is ecological economics?, Ecological Economics, vol. 1, no. 1, pp. 1-7.

Daly H.E., Farley J., 2010, Ecological Economics: Principles and Applications, Island Press, Washington.

Daniels P.L., 2003, Buddhist economics and the environment: Material flow analysis and the moderation of society's metabolism, International Journal of Social Economics, vol. 30, no. 1/2, pp. 8-33.

De Geus A., 2007, The Living Company: Growth, Learning and Longevity in Business, Nicholas Brealey Publishing, London.

Elsner W., Heinrich T., Schwardt H., 2014, Microeconomics of Complex Economies: Evolutionary, Institutional, and Complexity Perspectives, Elsevier, Amsterdam.

Felber C., 2010, Die Gemeinwohl-Ökonomie: das Wirtschaftsmodell der Zukunft, Deuticke, Wien.

Femia A., Hinterberger F., Luks F., 2001, Ecological economic policy for sustainable development: potentials and domains of intervention for delinking approaches, Population and Environment, vol. 23 , no. 2 , pp. 157-174.

Foster J., 2006, Why is economics not a complex systems science?, Journal of Economic Issues, vol. 40, no. 4, pp. 1069-1091.

Gowdy J., Erickson J.D., 2005, The approach of ecological economics, Cambridge Journal of Economics, vol. 29, no. 2, pp. 207-222.

Habermas J., 1987, The Theory of Communicative Action: Reason and the Rationalization of Society, Beacon Press, Boston.

Hodgson G.M., 2004, The Evolution of Institutional Economics, Routledge, London.

Horodecka A., 2008, Ewolucja celów polityki gospodarczej, PWN, Warszawa.

Horodecka A., 2011, Koncepcja homo sustinens i jej rola w polityce gospodarczej wobec wyzwań globalnego kryzysu, [in:] K. Pająk, J. Tomidajewicz (ed.), Polityka gospodarcza wobec globalnego kryzysu ekonomicznego, pp. 31-55, Wydawnictwo Adam Marszałek, Toruń.

Horodecka A., 2015a, The Changing Concept of Human Nature as the Answer to the Actual Problems of the Economics: The Neoclassical vs. Feminist Economics, Studia i Prace WNEiZ, vol. 2, no. 41 , pp. 25-32.

Horodecka A., 2015b, The field of evolutionary and neoclassical economics as a consequence of the changes in concepts of human nature, Journal of International Studies, vol. 8, no. 1, pp. 126-137. 
Horodecka A., 2015c, The impact of the human nature concepts on the goal of humanistic economics and religious motivated streams of economics (Buddhist, Islam and Christian), Rivista Internazionale di Scienze Sociali, vol. 123, no. 4, pp. 413-445.

Horodecka A., 2016a, Koncepcja człowieka a polityka zrównoważonego rozwoju, [in:] J. Stacewicz (ed.), Prace i Materiały Instytutu Rozwoju Gospodarczego SGH, Oficyna Wydawnicza SGH, Warszawa, pp. 171-204.

Horodecka A., 2016b, Obraz czlowieka we współczesnej ekonomii, unpublished manuscript, submitted to Oficyna Wydawnicza SGH (submitted), Warszawa.

Horodecka A., 2017, The methodology of evolutionary and neoclassical economics as a consequence of the changes in the concept of human nature, Argumenta Oeconomica, vol. 39, no. 2, It will be published in November 2017.

Jager W., Janssen M.A., 2000, The human actor in ecological-economic models (special issue), Ecological Economics, vol. 35, no. 3, pp. 307-418.

Kuran T., 1997, The genesis of Islamic economics: a chapter in the politics of Muslim identity, Social Research, vol. 64, no. 2, pp. 301-338.

Locke J., Laslett P., 1988, Two Treatises of Government, Cambridge University Press, Cambridge.

Lutz M.A., Lux K., 1979, The Challenge of Humanistic Economics, Benjamin/Cummings Pub. Co., Menlo Park.

Mlcoch L., 2007, Economics and happiness: Why more is sometimes not better, Politicka Ekonomie, vol. 55 , no. 2 , pp. 147-163.

Nelson R.R., Winter S.G., 1982, An Evolutionary Theory of Economic Change, Belknap Press of Harvard University Press, Cambridge.

Payutto P.A., 1994, Buddhist Economics, a Middle Way for the Market Place, Buddhadhamma Foundation, Bangkok.

Peter F., 2003, Critical realism, feminist epistemology, and the emancipatory potential of science: A comment on Lawson and Harding, Feminist Economics, vol. 9, no. 1, pp. 93-101.

Schumacher E.F., 1973, Small is Beautiful: A Study of Economics as if People Mattered, Blond and Briggs, London.

Sen A., 2008, Capability and Well-Being, [in:] D. Hausman (ed.), The Philosophy of Economics, Cambridge University Press, New York, pp. 270-294.

Stiglitz J., 2013, The Price of Inequality, W.W. Norton, London.

Tomer J.F., Eikelenboom B., 2008, Intangible Capital: Its Contribution to Economic Growth, Wellbeing and Rationality, Elgar, Cheltenham.

Tversky A., Kahneman D., 1974, Judgment under uncertainty: Heuristics and biases, Science, vol. 185, no. 4157, pp. 1124-1131.

Vozna L., 2013, The cessation of the synergistic factor of economic growth and financial crises, Working papers of STOREP, available: http://www.storep.org/wp/wp-content/uploads/2013/08/ STEP-2013-05-Vozna.pdf.

Vozna L., 2016, The notion of entropy in economic analysis: the classical examples and new perspectives, Journal of Heterodox Economics [Online] https://www.degruyter.com/view/j/ jheec.2016.3.issue-1/jheec-2016-0001/jheec-2016-0001.xml, vol. 3, no. 1, pp. 1-16. 